\title{
Efficiency of Voluntary Consumption of Amino Acid-chelated Iron in Preventing Anaemia of Suckling Piglets
}

\author{
M. SVOBODA, J. DRÁBEK
}

Clinic of Pig Diseases, Faculty of Veterinary Medicine,

University of Veterinary and Pharmaceutical Sciences, Brno, Czech Republic

Received June 12, 2003

Accepted September 22, 2003

\section{Abstract}

Svoboda M., J. Drábek: Efficiency of Voluntary Consumption of Amino Acid-chelated Iron in Preventing Anaemia of Suckling Piglets. Acta Vet. Brno 2003, 72: 499-507.

The aim of the study was to evaluate efficiency of voluntary access to amino acid-chelated iron in the form of mineral supplement in preventing anaemia of piglets. Piglets in group $1(n=60)$ were offered ad libitum the iron mineral supplement $\left(\mathrm{Fe} 110 \mathrm{~g} \cdot \mathrm{kg}^{-1}\right)$ from the $2^{\text {nd }}$ to the $14^{\text {th }}$ day of life. Piglets in group $2(\mathrm{n}=30)$ were given $200 \mathrm{mg} \mathrm{Fe}^{3+}$ as iron dextran i.m. on day 3. On day 7, haemoglobin concentration $(\mathrm{Hb})(P<0.05)$, packed cell volume $(P<0.05)$, red blood cell count $(P<0.01)$ and plasma iron concentration $(P<0.01)$ in group 1 were lower compared to group 2 . On day 14 and 21 no significant differences were found between the two groups. At the time of weaning (day 28), the voluntary access to iron did not prevent $8 \%$ of piglets from becoming anaemic $\left(\mathrm{Hb}<80 \mathrm{~g} \cdot \mathrm{l}^{-1}\right)$. Body weights were comparable in the 2 groups.

Haemoglobin, packed cell volume, erytrocyte

Iron deficiency anaemia is a serious problem in swine production. The piglet can receive only ca $1 \mathrm{mg}$ Fe per day from sow's milk (Cs apó 1995; Kleinbeck and McGlone 1999). However the daily requirement during suckling period is ca 7-10 mg Fe (Venn et al. 1947). The iron deficit results in clinically apparent anaemia 10-14 days postpartum (Framstad and Sjaastad 1991; Zimmermann 1995). Different forms of iron supplementation have been used in order to prevent the development of iron deficiency anaemia in piglets. Parenteral or oral preparations for iron supply are available. The amino acid-chelated iron is one of the possibilities for oral iron supplementation to pigs. The iron chelates remain intact in gastrointestinal tract due to their high complex stability (S mitz and Müller 1971; De Wayne 1975) and they are absorbed as amino acid complex or small peptides. A high absorption rate is therefore achieved (A shmead 1993). Chelates are also believed to cross to some extend the placental barrier. However, attemps to prevent the development of anaemia in piglets by treating pregnant sows with amino acid-chelated iron were not successful (Akabayashi et al. 1989; Egeli et al. 1998a). The iron chelates offered to suckling piglets in drinking water as a sole source of iron were not fully efficient (Egeli and Framstad 1998).

The aim of the present paper was to evaluate the efficiency of voluntary uptake of amino acidchelated iron in the form of mineral supplement in preventing iron deficiency anaemia of piglets.

\section{Materials and Methods}

Experimental design

The sows and their litters were kept in farrowing crates until weaning. All the piglets were weaned on day 28. Prestarter (iron content - Fe $248 \mathrm{mg} \cdot \mathrm{kg}^{-1}$ ) were offered to piglets ad libitum from day 14-35. The piglets were individually tatooted with a number in the ear. The piglets were not subjected to castration or tail docking. The piglets were divided into 3 groups.

Address for correspondence:

MVDr.Martin Svoboda, PhD

(2)

lackého 1-3, 61242 Brno

Czech Republic
Phone: +420 541562433

Fax: +420574884

http://www.vfu.cz/acta-vet/actavet.htm 
Group 1: Experimental group

Group 1 had 60 piglets from 6 litters. The piglets were offered ad libitum mineral supplement (PrimoFer) with high content of amino acid-chelated iron (iron content $-\mathrm{Fe} 110 \mathrm{~g} \cdot \mathrm{kg}^{-1}$ ) from $2^{\text {nd }}$ to $14^{\text {th }}$ day of life. The mineral supplement contained: humidity $8 \%$, fat $130 \mathrm{~g} \cdot \mathrm{kg}^{-1}, \mathrm{~N}$-compounds $70 \mathrm{~g} \cdot \mathrm{kg}^{-1}$, fiber $50 \mathrm{~g} \cdot \mathrm{kg}^{-1}, 1 \mathrm{sin} 35$ $\mathrm{g} \cdot \mathrm{kg}^{-1}$, ash $220 \mathrm{~g} \cdot \mathrm{kg}^{-1}$, copper $\left(\mathrm{CuSO}_{4} \cdot 5 \mathrm{H}_{2} \mathrm{O}_{2}\right) 750 \mathrm{mg} \cdot \mathrm{kg}^{-1}$, amino acid-chelated iron - Fe $110 \mathrm{~g} \cdot \mathrm{kg}^{-1}$, vitamin A 100000 UI, vitamin D 15000 UI, vitamin E (alfatocoferol) $500 \mathrm{mg} \cdot \mathrm{kg}^{-1}$, Bacillus subtilis and Bacillus licheniformis $(1: 1) 6.25 \cdot 10^{9} \mathrm{CFU} \cdot \mathrm{kg}^{-1}$. It is known that piglets in the first days of life receive almost exclusively sow's milk and are not used to take solid supplements. That is why maximal accessibility of such preparations to piglets must be ensured (Nells sen et al. 1999). In order to maximize the accessibility to piglets, the mineral supplement was placed on a low feeding slab on the line between the sow and the piglets corner out of reach of the sow.

Group 2: Positive control group

Group 2 had 30 piglets from 3 litters. The piglets were injected i.m. with $200 \mathrm{mg} \mathrm{Fe}^{3+}$ in the form of iron dextran on the $3^{\text {rd }}$ day of life.

Group 3: Negative control group

Group 3 had 20 piglets from 2 litters. The piglets were not given any iron preparation till the 21 days of age. On day 21, the piglets were injected i.m. $200 \mathrm{mg} \mathrm{Fe}^{3+}$ in the form of iron dextran.

Sampling and analyses

Blood ( $2 \mathrm{ml})$ was collected from the piglets on days 7, 14, 21, 28 and 35 from the cranial vena cava. EDTA (ethylenediaminetetraacetic acid) was used as anticoagulant for haematological examination. Heparin was used as anticoagulant for determination of iron concentration in blood plasma.

Haematological examination included: haemoglobin concentration $(\mathrm{Hb})$, packed cell volume (PVC), red blood cell count (RBC), mean corpuscular volume (MCV), mean corpuscular haemoglobin concentration $(\mathrm{MCHC})$ and mean corpuscular haemoglobin $(\mathrm{MCH})$. $\mathrm{Hb}$ was measured photometrically using cyanomethaemoglobin method. PCV was measured using standard capillary tubes and centrifugation in a microhematocrit centrifuge. Erytrocytes were counted in Bürker's chamber using Haym's solution. MCV, $\mathrm{MCH}$ and MCHC were calculated.

Iron concentration in blood plasma $(\mathrm{Fe})$ was determined photometrically measuring iron complex with ferrozin.

The piglets were weighed (BW) at birth (day 1) and on days 7, 14, 21, 28, 35.

Statistical analyses

The results were evaluated statistically by Mann-Whitney $U$ test.

\section{Results}

Differences of examined indices between groups

Day 7

$\mathrm{Hb}(P<0.05), \mathrm{PCV}(P<0.05), \mathrm{RBC}(P<0.01)$ and $\mathrm{Fe}(P<0.01)$ in group 1 (iron chelate) were lower than in group 2 (iron dextran). In group 3 (anaemic group), $\mathrm{Hb}(P<0.01), \mathrm{PCV}$ $(P<0.01)$, RBC $(P<0.05), \mathrm{MCV}(P<0.01)$, MCH $(P<0.05)$ and $\mathrm{Fe}(P<0.01)$ were lower compared to group 2.

Day 14

PCV $(P<0.05)$, MCV $(P<0.01)$ and $\mathrm{Fe}(P<0.05)$ in group 1 was higher compared to group 2. MCHC $(P<0.01)$ in group 1 was lower then in group 2 . $\mathrm{Hb}(P<0.01)$, PCV $(P<$ $0.01), \operatorname{RBC}(P<0.01), \operatorname{MCV}(P<0.01), \operatorname{MCH}(P<0.01), \operatorname{MCHC}(P<0.05), \operatorname{Fe}(P<0.01)$ and BW $(P<0.01)$ in group 3 were lower than in group 2.

Day 21

In group 3, Hb, PCV, RBC, MCV, MCH, MCHC and BW (all, $P<0.01$ ) were lower than in groups 1 and 2 . Fe $\left(3.45 \pm 0.98 \mu \mathrm{mol} \cdot \mathrm{l}^{-1}\right)$ in group 3 on day 21 was comparable to days 7 and 14.

Day 28

$\mathrm{Hb}(P<0.05), \mathrm{MCV}(P<0.05), \mathrm{MCH}(P<0.05)$ and $\mathrm{Fe}(P<0.01)$ in group 1 were lower than in group 2. In group 3, BW were lower compared to groups 1 and 2.

Day 35

$\mathrm{Hb}(P<0.01), \mathrm{MCV}(P<0.05), \mathrm{MCH}(P<0.01)$ and MCHC $(P<0.01)$ in group 1 were lower than in group 2 . In group $3, \mathrm{BW}$ were lower compared to groups 1 and 2 . 
Development of examined indices within groups

Group 1

Between days 7 and 14, $\mathrm{Hb}(P<0.01), \mathrm{PCV}(P<0.01), \mathrm{RBC}(P<0.01), \mathrm{MCV}(P<0.01)$, $\mathrm{MCH}(P<0.01)$ and $\mathrm{Fe}(P<0.01)$ increased significantly. From day 21 to day 28 , there was a significant decrease in $\mathrm{Hb}, \mathrm{PCV}, \mathrm{MCV}$ and $\mathrm{MCH}$ (all $P<0.01$ ). From day 14 to day 28, Fe $(P<0.01)$ decreased significantly.

Group 2

Between days 7 and 14, there was significant increase in $\mathrm{Hb}(P<0.01)$, PCV $(P<0.01)$, $\mathrm{RBC}(P<0.01)$, and $\mathrm{MCH}(P<0.01)$. From day 21 to day 28 , all the indices remained to be statistically comparable.

Group 3

From day 7 to day $21, \mathrm{Hb}(P<0.01), \mathrm{PCV}(P<0.05), \mathrm{MCH}(P<0.01)$ and $\mathrm{MCHC}(P<$ 0.01 ) decreased significantly. From day 21-28 (after iron dextran injection), Hb, PCV, RBC, $\mathrm{MCV}, \mathrm{MCH}$ and MCHC (all $P<0.01$ ) increased significantly.

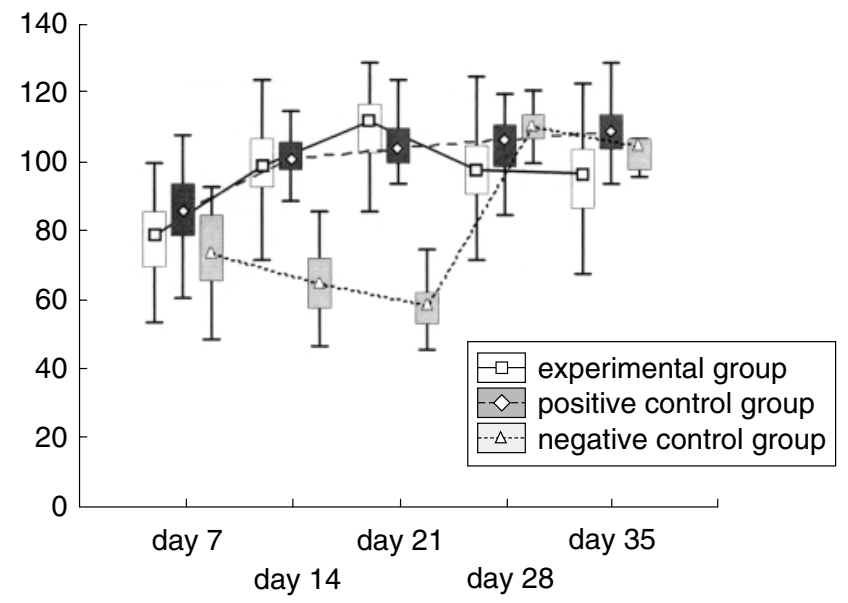

Fig. 1a. Haemoglobin concentration - comparison between groups $\left(\mathrm{Hb}, \mathrm{g} \cdot \mathrm{l}^{-1}\right)$

Experimental group

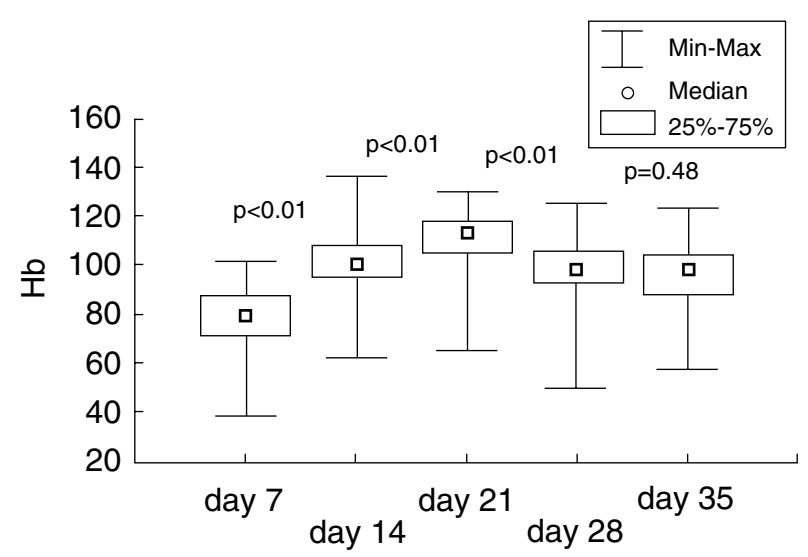

Fig. 1b. Haemoglobin concentration in experimental group $\left(\mathrm{Hb}, \mathrm{g} \cdot \mathrm{l}^{-1}\right)$ 


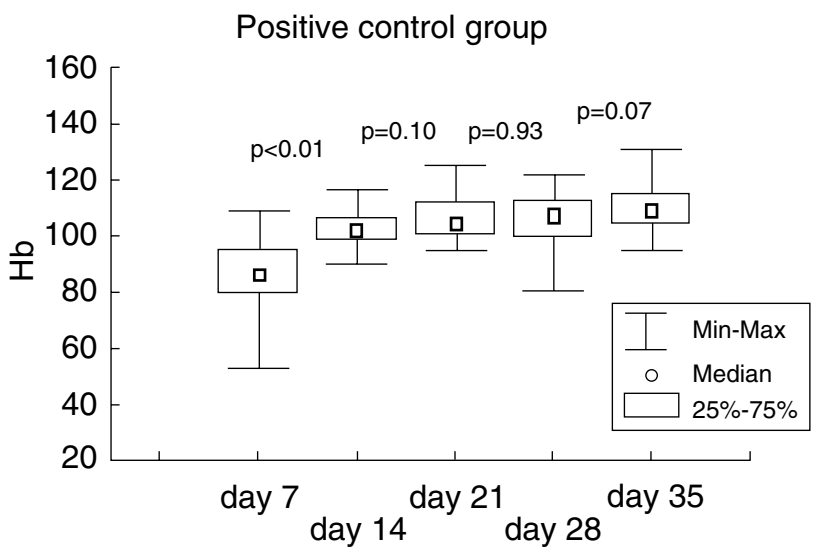

Fig. 1c. Haemoglobin concentration in positive control group (Hb, g. $\left.1^{-1}\right)$

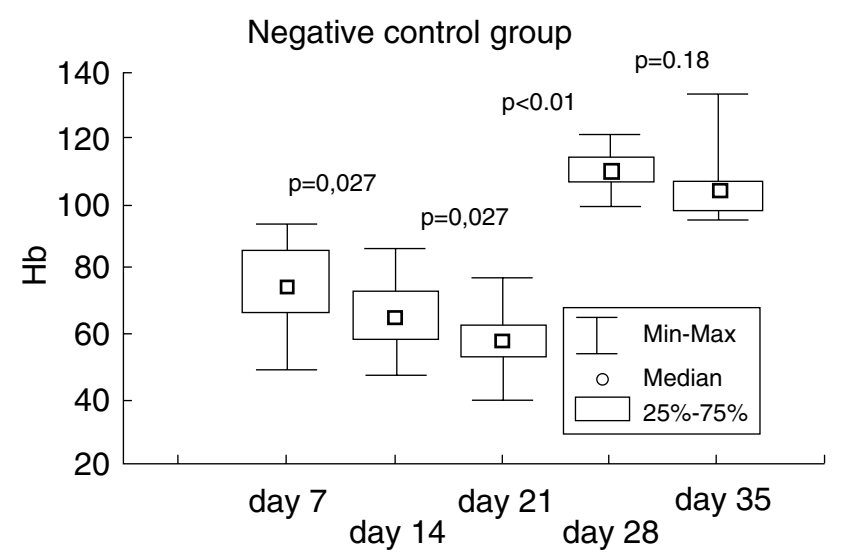

Fig. 1d. Haemoglobin concentration in negative control group (Hb, g. $\left.\mathrm{l}^{-1}\right)$

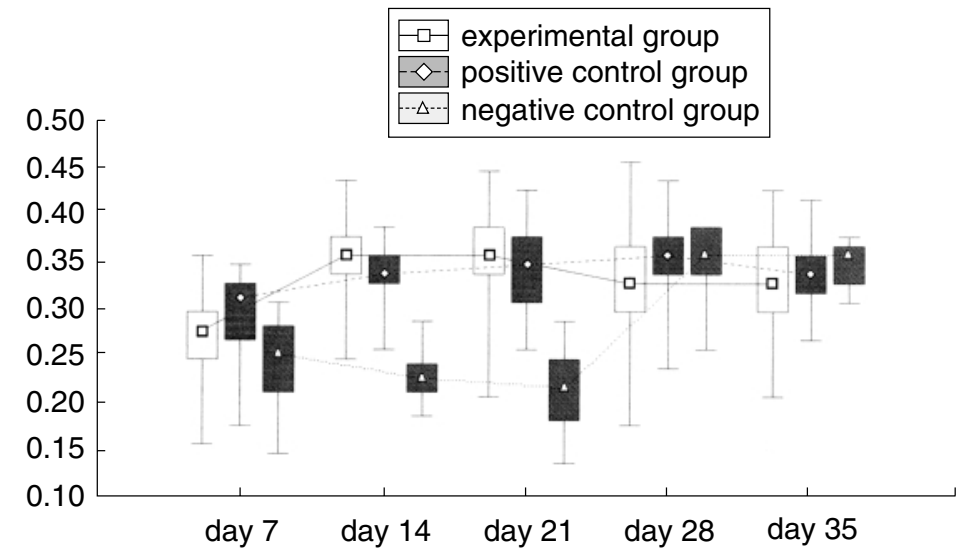

Fig. 2. Packed cell volume (PCV, $\left.1 \cdot 1^{-1}\right)$ 


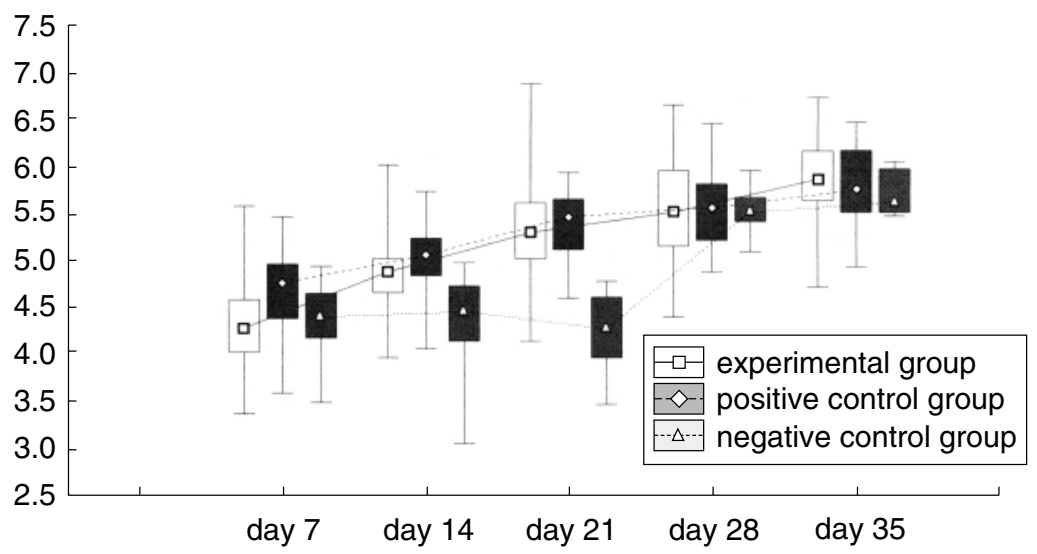

Fig. 3. Red blood cell count (RBC, $\left.T \cdot \cdot^{-1}\right)$

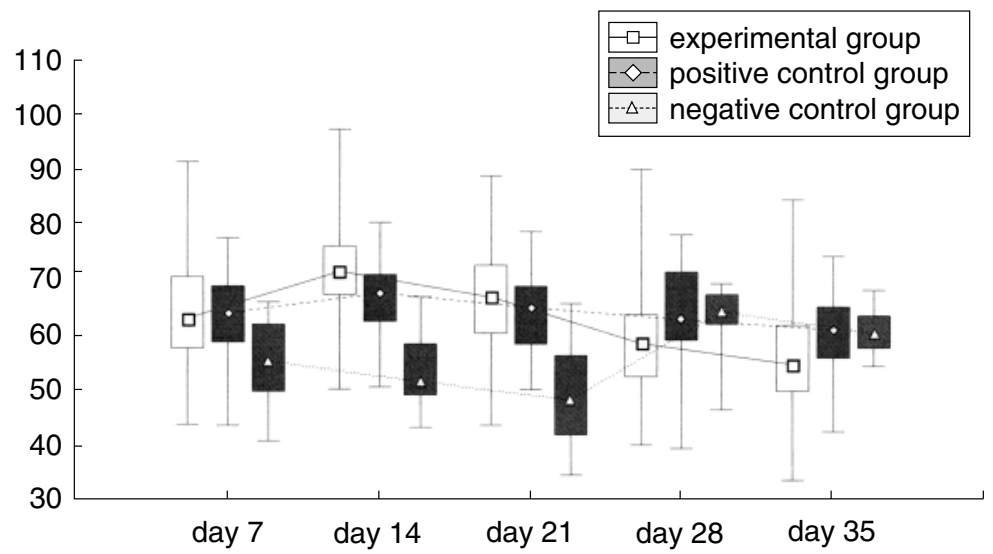

Fig. 4. Mean corpuscular volume (MCV, fl)

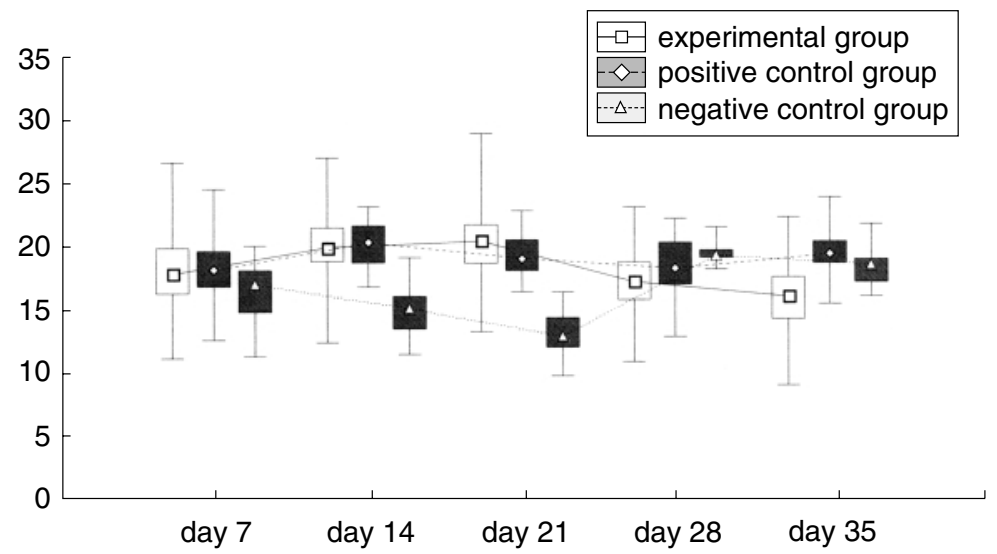

Fig. 5. Mean corpuscular haemoglobin (MCH, pg) 
504

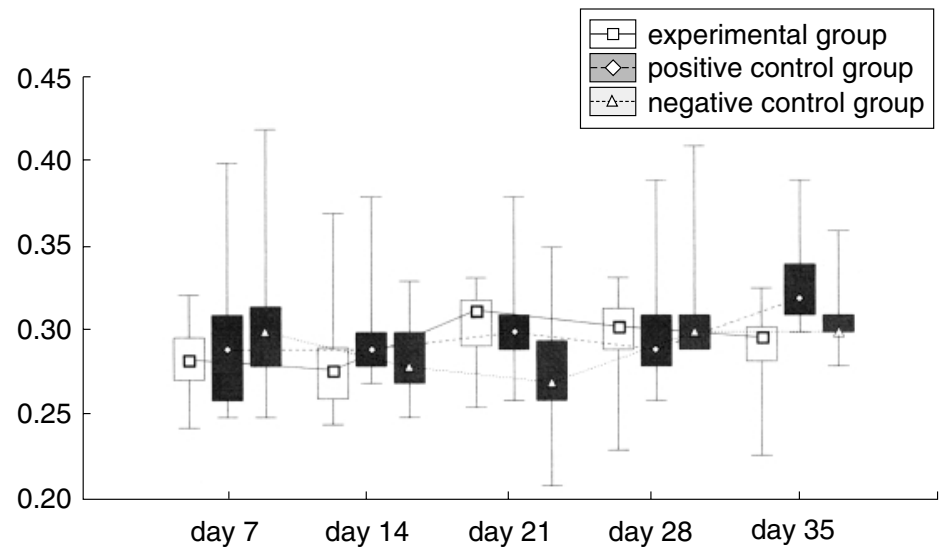

Fig. 6. Mean corpuscular haemoglobin concentration (MCHC, g. $1^{-1}$ )

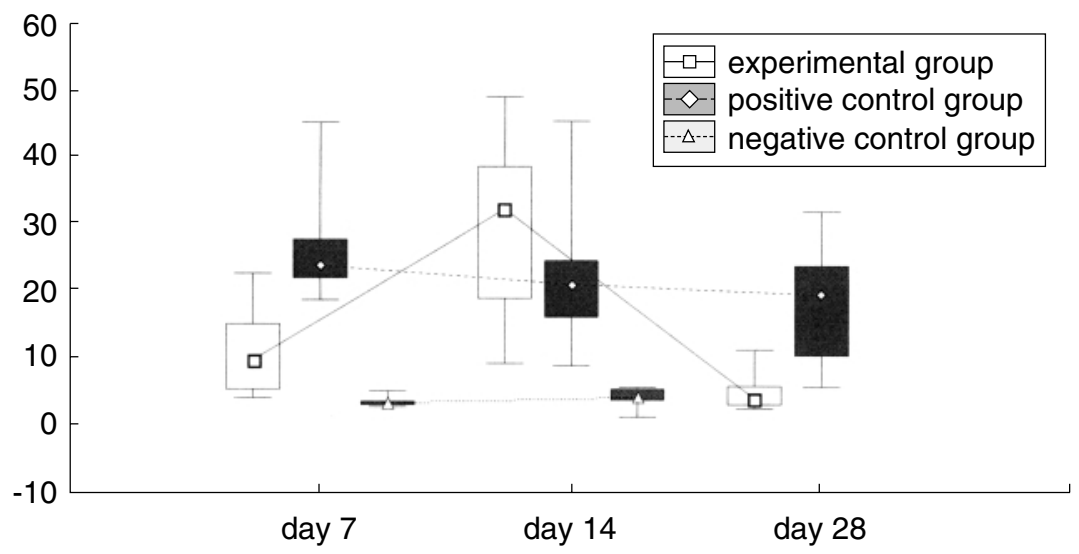

Fig. 7. Fe concentration in blood plasma $\left(\mathrm{Fe}, \mu \mathrm{mol} \cdot \mathrm{l}^{-1}\right)$

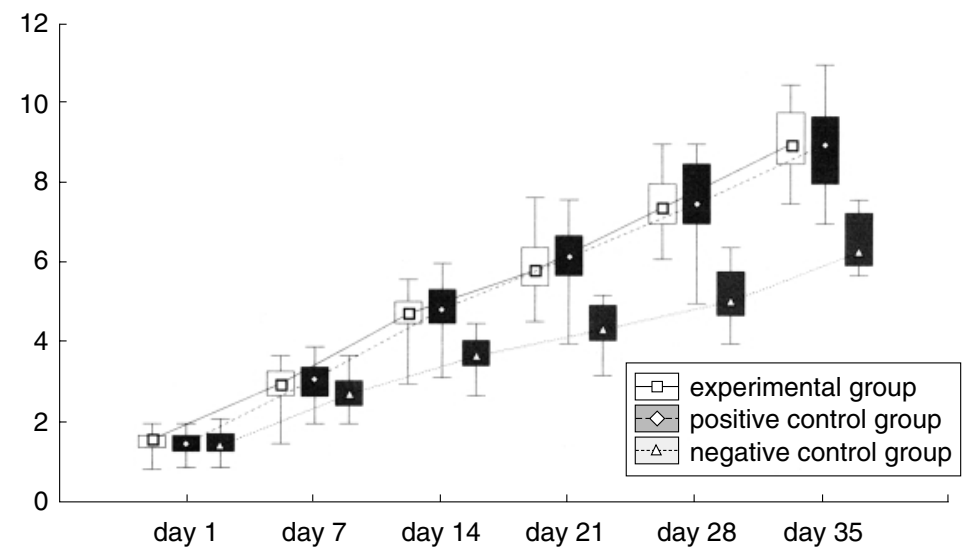

Fig. 8. Body weight (BW, kg) 


\section{Discussion}

For oral administration iron-containing paste is used most often. Another possibility is voluntary uptake of iron containing preparations offered to piglets ad libitum. It is generally agreed that application of such preparations in drinking water is not recommended, because as long as piglets suckle they are not really interested in other water sources (Zi m mer man 1995; Jörgensen and Brun 2000; Egeli and Framstad 1998). Bollwahn and Shulze-Steinen (1966), Zimmermann (1995). Jörgensen and Brun (2000) prevented piglets from becoming anaemic by offering them highly concentrated iron powder from $2^{\text {nd }}$ day of life till the time of weaning. The iron powder contained high concentration of iron-fumarate or a combination of iron-sulphate and iron-fumarate.

The iron chelates in the form of mineral supplement were used so far only as an additional source of iron for voluntary uptake by piglets after single iron application (Egeli et al. 1998b; Jörgenssen and Brun 2000). Our attempt was to evaluate the efficiency of amino acid chelated iron mineral supplement as the sole source of iron for piglets.

It is considered that the voluntary consumption of oral preparation by piglets during the first week of life will be inadequate (Egeli and Framstad 1998). This was confirmed also in our study. We have found significantly lower $\mathrm{Hb}(P<0.05), \mathrm{PCV}(P<0.05), \mathrm{RBC}(P<$ $0.01)$ and $\mathrm{Fe}(P<0.01)$ in group 1 on day 7 than in group 2 . The anaemic limit, i.e. the point when anaemia begins to have a detrimental effect on weight gain or give rise to clinical symptoms of anaemia is set by most authors at a haemoglobin concentration of $80 \mathrm{~g} \cdot \mathrm{l}^{-1}$ (Furugouri 1975; van Kempen 1987).

In group 1 , on day 7 , there were $48.3 \%$ of piglets found anaemic (i.e. $\mathrm{Hb}<80 \mathrm{~g} \cdot \mathrm{l}^{-1}$ ). This indicates an uneven and insufficient voluntary uptake of the oral iron preparation at this age.

In group 2, on day 7, there were also anaemic piglets $\left(\mathrm{Hb}<80 \mathrm{~g} \cdot \cdot^{-1}\right)$, but their percentage was much lower $(23.3 \%)$. The occurrence of anaemic piglets in iron dextran injected group on day 7 is in agreement with findings of Iben (1998), Egeli and Framstad (1999), Lemacher and Bostedt (1995) and can be explained by delayed availability of iron for haemoglobin syntesis. This delay is caused by an uptake of iron dextran by reticulohistiocytic system. From the injection site the iron dextran is at first taken up by phagocytic cells (Kolb et al. 1992). The dextran component is then decomposed by lysosomal enzymes of phagocytes and stored as ferritin (Katkiew icz et al. 1986). The iron binds then to transferrin and is moved to the areas of need (Murray et al. 2000).

From day $14-35$ no anaemic piglets $\left(\mathrm{Hb}<80 \mathrm{~g} \cdot \mathrm{l}^{-1}\right)$ were found in group 2. In group 1 on day 14 and 21, no anaemic piglets were present and values of examined parameters were comparable to group 2. However, from day 21-28, Hb, PCV, MCV and MCH (all, $P<0.01$ ) in group 1 decreased significantly and $8.2 \%$ of anaemic piglets $\left(\mathrm{Hb}<80 \mathrm{~g} \cdot \mathrm{l}^{-1}\right)$ were detected. Also the plasma iron concentration in group 1 decreased from day 14 to day 28 $(P<0.01)$ and were significantly lower compared to group 2 . These declines indicate that the iron reserves of piglets in group 1 at the time of weaning began to be depleted. According to Steinhardt et al. (1984), the risk of development of anaemia in piglets is greatest at the time of weaning. Therefore more attention is paid to control of iron supply at the time of weaning.

The lower values of the examined indices on day 7 and their decreasing tendency at the time of weaning (day 28) in group 1 did not result in a lower body weight compared to group 2 .

The results in anaemic group (group 3) were as expected, i.e. - hypochromic anaemia developed and resulted in growth retardation of piglets.

We conclude that voluntary access to amino acid-chelated iron prevented anaemia in the majority of the weaning piglets and resulted in a growth intensity comparable to piglets injected with iron dextran. 


\section{Účinnost dobrovolného příjmu aminokyselinového chelátu železa v prevenci anémie sajících selat}

Cílem práce bylo zhodnotit účinnost dobrovolného př́ijmu aminokyselinových chelátů železa ve formě minerálního doplňku pro prevenci anémie selat. Prasatům ve skupině 1 (n= 60) byl předkládán železitý minerální doplněk $\left(\mathrm{Fe} 110 \mathrm{~g} \cdot \mathrm{kg}^{-1}\right)$ od 2. do 14 . dne života. Selatům ve skupině $2(\mathrm{n}=30)$ bylo třetí den života aplikováno i.m. $200 \mathrm{mg} \mathrm{Fe}{ }^{3+}$ vázaného na dextran. Sedmý den života byla koncentrace hemoglobinu $(\mathrm{Hb})(P<0,05)$, hodnota hematokritu $(P<$ $0,05)$, počet červených krvinek $(P<0,01)$ a koncentrace železa v plazmě $(P<0,01)$ ve skupině 1 nižší ve srovnání se skupinou 2. Čtrnáctý a 21. den nebyly mezi oběma skupinami zjištěny rozdíly. Při odstavu (28. den) nezabránil dobrovolný př́ijem železa vzniku anémie u 8,2\% selat $\left(\mathrm{Hb}<80 \mathrm{~g} \cdot \mathrm{l}^{-1}\right)$. Hmotnosti selat byly v obou skupinách srovnatelné.

\section{Acknowledgements}

Supported by the Ministry of Education, Youth and Sports of the Czech Republic (Grant No. 161700002).

\section{References}

AKABAYASHI, TW, YAMAMOTO, M, HIRAY, Y, YOSHINO, Y 1989: Absorption and availability of iron peptide in pregnant sows. Bull Nippon Vet Zootech Coll 38: 93-105

ASHMEAD, HD 1993: The roles of amino acid chelates in animal nutrition. Noyes Publications. Park Ridge, New Jersey, pp. 47-75, 207-230

BOLLWAHN, W, SCHULZE-STEINEN, H 1966: Über die Wirksamkeit der Anämieprophylaxe bei Saugferkeln. Zetrbl Veterinärmed (B) 13: 119-124

CSAPÓ, JE 1995: Protein, fats, vitamins and mineral concentration in porcine colostrum and milk from parturion to 60 days. Int Dair J 6: 881-902

DEWAYNE, A 1975: Prevention of baby pig anemia with amino acid chelates. Vet Med Small Anim Clin 70: 607610

EGELI, AK, FRAMSTAD, T, GRONNINGEN, D 1998a: The effect of peroral administration of amino acidchelated iron to pregnant sows in preventing sow and piglet anaemia. Acta vet Scand 39: 77-87

EGELI, AK, FRAMSTAD, T 1998: Effect of oral starter dose of iron on haematology and weight gain in piglets having voluntary access to glutamic acid-chelated iron solution. Acta vet Scand 39: 359-365

EGELI, AK, FRAMSTAD, T, MORBERG, H 1998b: Clinical biochemistry, haematology and body weight in piglets. Acta vet Scand 39: $381-393$

EGELI, AK, FRAMSTAD, T 1999: An evaluation of iron-dextran supplementation in piglets administered by injection on the first, third or fourth day after birth. Res Vet Sci 66: 179-184

FRAMSTAD, T, SJAASTAD, O 1991: Iron supplementation in piglets. Norsk Veterinaertidsskrift 103: 21-27

FURUGOURI, K 1975: Characteristic aspects of iron metabolism in piglets. Jap Agric Res Q 9: 171

IBEN, B 1998: Bedeutung der peroralen Eisengabe bei Ferkeln in den ersten Lebensstunden. Tierärztl Prax 26: 3639

JÖRGENSEN, A, BRUN, E 2000: Haematological status in 3 week piglets in herds with different strategies for iron supply. Proc. $16^{\text {th }}$ IPVSC, Melbourne, p. 192

KATKIEWICZ, M, MALICKA, E, PREIBISCH, J 1986: Effect of iron overload on the morphology of some organs in piglets. Pol Arch Vet 25: 75

KLEINBECK, S, MCGLONE, J 1999: Intensive indoor versus outdoor production systems: Genotype and supplemental iron effects on blood haemoglobin and selected immune measures in young pigs. J Anim Sci 77: 2384-2390

KOLB, E, HOFFMANN, U, NESTLER, K 1992: Untersuchungen über den Gehalt an Eisen, Kupfer und Zink in verschiedenen Geweben (Magen-Darm-Kanal, Lymphknoten, Muskulatur, Herz, Leber, Milz, Niere, Pankreas, Knochenmark) bei neugeborenen Ferkeln nach oraler und intramuskulare Verabreichung von Fe-Dextran. Mh Vet Med 47: 271-278

LEMACHER, S, BOSTEDT, H 1995: Entwicklung der Eisenversorgung von Saugferkeln bei unterschiedlicher Eisensupplementierung unter Berücksichtigung der Haltungsbedingungen. Tierärztl Prax 23: 457-464

MURRAY, R, GRANNER, DK, MAYES, PA, RODWELL, VW 2000: Harper's Biochemistry. $25^{\text {th }}$ Edition, Appleton \& Lange, Stamford, p. 927

NELSSEN, JL, DRITZ, SS, TOKACH, MD, GOODBAND, RD 1999: Nutritional programs for segregated early weaning. In: Diseases of swine $8^{\text {th }}$ ed. Straw, B. E., D`Allaire S., Mengeling, W. L., Taylor, D J Iowa State Univ Press, pp. 1045-1055

SMITZ, H, MÜLLER, A 1971: Vergleichende Untersuchung über die therapeutische Wirkung oral applizierter Eisen (II) - bzw. Eisen (III)-Antianämica. Arzneim Forsch 21: 509-515 
STEINHARDT, M, BÜNGER, U, FURCHT, G 1984: Zum Eisenbedarf des Schweines in der ersten 2 Lebensmonaten. Arch Exper Vet Med 38: 497-515

VAN KEMPEN, GJM 1987: Avoid iron deficiency in piglets. Pigs 3: 10-11

VENN, JAJ, MCCANCE, RA, WIDDOWSON, EM 1947: Iron metabolism in piglet anemia. J Comp Path 57: 314 325

ZIMMERMANN, W 1995: Auswirkungen diverser Anämieprohylaxeformen auf die Blutparameter der Saugferkel. Dtsch tierärztl Wschr 102: 32-38 